\title{
Chayotextle flour as raw material for prebiotic gluten-free cookies added with Agave angustifolia Haw fructans
}

\author{
Harina de Chayotextle como materia prima de galletas prebióticas libres de gluten adicionadas con \\ fructanos de Agave angustifolia Haw
}

\begin{abstract}
Wendy Magaly Arias Balderasa, Miguel Ángel Aguilar Méndeza, Marluci Palazzolli-da Silvab, Carmen Silvia FávaroTrindade ${ }^{b}$, Fernanda Maria Vanin ${ }^{b}$, Delia Quintana-Zavala**

a Centro de Investigación en Ciencia Aplicada y Tecnología Avanzada Unidad Legaria del Instituto Politécnico Nacional. Legaria 694. Colonia Irrigación, Alcaldía Miguel Hidalgo, Ciudad de México, C.P. 11500. México.

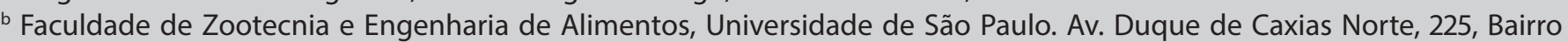
Jardim Elite, Pirasssununga, São Paulo, Brasil.
\end{abstract}

\section{ABSTRACT}

Some plants, roots or tubers have been used as possible cereal substitutes in gluten-free cookies. Chayotextle is rich in starch and other compounds that could make it a potential ingredient for products aimed at the celiac population. In this study, we evaluated the effect of different mixtures of rice flour (RF) and Chayotextle flour (CF) on the final properties of cookies and the prebiotic capacity when adding agave fructans (AF). The properties of flour and cookies were determined. CF presented the highest emulsifying, water absorption and oil absorption (27.1\%, 66.22 $\%$ and $95.93 \%$, respectively) capacities. Cookies made with CF-AF reached the highest values in diameter $(66.82 \mathrm{~mm})$ and humidity (10.64\%). By incorporating rice flour to this combination, cookies had the highest thickness (10.04 mm), specific volume $(2.07 \mathrm{~mL} / \mathrm{g})$, and hardness (201.82 N). CF and the CF-AF formulation presented the ability to promote the growth of both strains studied: Lactobacillus acidophilus LA-3 and Bifidobacterium animalis ssp. Lactis, reaching values of up to $9.82 \log _{10} \mathrm{CFU} / \mathrm{mL}$ and $9.85 \log _{10}$ CFU/mL (CF) respectively, in a period of $24 \mathrm{~h}$. The CF and the addition of FA improved cookies properties, and proved to be a possible prebiotic source.

Keywords: Agave fructan, prebiotic capacity, cereal substitute, root.

\section{RESUMEN}

Algunas plantas, raíces o tubérculos han sido explotados como posibles sustitutos de cereales en galletas libres de gluten. El Chayotextle es rico en almidón y otros compuestos que podrían convertirlo en ingrediente potencial para productos dirigidos a la población celiaca. En este estudio, el efecto de distintas mezclas de harinas de arroz (RF) y Chayotextle (CF) sobre las propiedades finales de galletas y capacidad prebiótica al adicionar fructanos de agave (AF) fueron evaluadas. Las propiedades de las harinas y de galletas fueron determinadas. CF presentó la mayor capacidad emulsificante, de absorción de agua y de aceite $(27.1 \%, 66.22$ \% y $95.93 \%$, respectivamente). Las galletas realizadas con CF y FA alcanzaron los mayores valores en diámetro $(66.82 \mathrm{~mm}$ )

\section{Volumen XXIII, Número 2}

y humedad (10.64\%). Al incorporar harina de arroz a esta combinación las galletas mostraron el mayor espesor (10.04 $\mathrm{mm}$ ), volumen específico (2.07 mL / g) y dureza (201.82 N). CF y la formulación CF-AF mostraron capacidad de promover el crecimiento de ambas cepas estudiadas: L. acidophilus LA-3 y B. animalis ssp. Lactis, alcanzando valores de $9.82 \log _{10}$ UFC/ $\mathrm{mL}$ y $9.85 \log _{10}$ UFC/mL (CF) a las 24 h. CF y la adición de FA mejoraron las propiedades en galletas y mostraron ser una posible fuente prebiótica.

Palabras clave: fructano de agave, capacidad prebiótica, sustituto de cereales, raíz.

\section{INTRODUCTION}

A functional food is that which provides some benefit to health and/or reduces the risk of disease (Pérez, Jaimez \& Contreras, 2017). Currently, there is not a globally accepted definition for this type of food. However, it is known that this term began in Japan with the legalization of beneficial foods with healthy properties, under the FOSHU (Food for Specified Health Use) definition (Fuentes et al., 2015). Likewise, the European Union created a FUFOSE (Functional Food Science in Europe) regulatory commission, under the coordination of ILSI (International Life Sciences Institute), which defined as a functional food, that which has satisfactorily demonstrated that in addition to providing adequate nutrition, it provides some additional health benefit or reduces the risk of disease (Pérez, Jaimez \& Contreras, 2017). On the other hand, the FDA classified some categories of food with additional properties, such as conventional foods, food additives, dietary supplements, etc (Sarmiento, 2006).

This type of food may contain a nutrient or non-nutrient component in which we can find prebiotics, such as some kinds of fiber, fructans, resistant starch oligosaccharides, to name a few, which are present in some fruits, tubers and roots of some plants (Chandrasekara y Kumar, 2016). Likewise, they may also contain some microorganisms that are considered probiotics (Leidi et al., 2018), or some bioactive component such as antioxidant compounds, which gives them the character of functional food.

*Autor para correspondencia: Delia Quintana Zavala Correo electrónico: dquintana@ipn.mx Recibido: 11 de agosto de 2020 Aceptado: 8 de febrero de 2021 
Chayotextle is a tuberized root of the chayote plant (Sechium edule) which grows in some states of Mexico and belongs to the cucurbit family (Cruz, 2017). It is characterized by containing large amounts of starch, dietary fiber and phenolic compounds that provide health benefits for those who consume it (Shiga et al., 2015). Generally, this tuber is consumed as a cooked vegetable in traditional cuisine; however, its use in the form of flour extends its shelf life. In this form, it can be incorporated as an ingredient in bakery products by replacing, totally or partially, the common flours of some cereals such as corn or wheat (Moro et al., 2018), which would allow the production of gluten-free products for people with celiac disease and those wanting to reduce gluten in their diet. Nowadays, there are no previous studies on Chayotextle flour use as an ingredient in bakery products, which is why there is no evidence about drawbacks in its use. However, the starch content in this type of flour, shows great characteristics that give the idea that it can be a good option in the development of gluten-free pasta or cookies production, with rapid digestibility, texture, and appearance, similar to the conventional starch obtained from wheat flour (González et al., 2017). On the other hand, there are several studies about the use of fructooligosaccharides and fructans addition in the manufacturing of bakery products, mainly in bread. Fructans addition in bread improved the technological and sensory properties; bread increased its volume and decreased in crumb hardening rate (Drabińska et al., 2016).

Fructooligosaccharides (FOS) are non-digestible oligosaccharides, which are able to resist the hydrolytic action of saliva and small intestine enzymes (Romano et al., 2019). They are degraded in the colon by bacteria, producing short chain fatty acids such as acetate, propionate, and butyrate (De Paulo et al., 2019).

Fructans are fructose polymers, which can contain up to 70 units of fructose (Ritsema y Smeekens, 2003), some of which may have a sucrose molecule at the terminal position. They have a linear or branched structure, linked together by $\beta-(2,6)$ or $\beta-(2,1)$ - fructosyl-fructose bonds, forming levana or inulin type fructans, respectively (Cuevas et al., 2017). Agave angustifolia, a plant of the Agavaceae family, is an important source of fructans in Mexico. Various studies have shown branched series of neofructans, called agavines, in the plant stem (pineapple) (Santiago et al., 2017), which are capable of promoting bifidobacterium and lactobacillus growth, and therefore, they can be considered as prebiotic agents (Koenen et al., 2016). Agavins, also known as agave inulin neoseries, have a complex mixture of highly branched fructans with $\beta-(2-1)$ and $\beta-(2-6)$ bonds in their structure (Mancilla-Margalli and López, 2006). Likewise, different studies reveal that fructans, especially of the inulin type, impart good technological properties to the food matrix to which they are added (Da Silva and Conti-Silva, 2018). Consequently, their use in bread, cookies, yogurt, and dairy products is becoming more frequent (Luo et al., 2017) thus improving appearance, texture, and in some cases, flavor (Rubel et al., 2014).
The objective of this study was to analyze the physicochemical properties, texture and prebiotic functionality of different gluten-free cookies formulations, developed from chayotextle flour and rice flour with added Agave angustifolia Haw fructans.

\section{MATERIALS AND METHODS Raw materials}

Chayotextle Flour (CF) was provided by the Organic Chemistry Laboratory (CICATA-Legaria, IPN, México), agave fructans (AF) were obtained from CEPROBI-IPN pilot plant (Yautepec, Morelos, México, Patent MX / a / 2015/ 016512), rice flour (RF) and other baking ingredients used (brown sugar, baking powder, salt, egg, and margarine) were purchased from a local market in Pirassununga (Sao Paulo, Brazil). De Man, Rogosa and Sharpe (MRS) culture media from Acumedia (Michigan) was used. Lactobacillus acidophilus LA-3 and Bifidobacterium animalis subsp. lactis BLC-1 were purchased from Sacco, Italy.

\section{Physical and physicochemical properties of flours}

Moisture content: It was determined through method 925.45 according to the AOAC (2006); samples of $3 \mathrm{~g}$ were used for the analysis and were placed into an oven at $100-105^{\circ} \mathrm{C}$.

pH: It was determined through the AOAC method (2006); 10 $\mathrm{g}$ of flour sample was mixed with $100 \mathrm{~mL}$ of distilled water at $25^{\circ} \mathrm{C}$. The mixtures were stirred in a Ma-420 incubator shaker, Marconi (Brazil), at $150 \mathrm{rpm}$ for $30 \mathrm{~min}$. Subsequently, they were allowed to stand for $10 \mathrm{~min}$ and the measurement was performed using a 3210 WTW pH potentiometer, Sensoglass (Germany).

Instrumental color: It was determined with a Hunter Lab MiniScan EZ colorimeter, Reston (USA), using the coordinates of the $C I E-L^{*} a^{*} b^{*}$ system, where $a^{*}$ negative $=$ red and $a^{*}$ positive $=$ green; and $b^{*}$ from negative (blue) to positive (yellow) (Alves et al., 2018).

Water activity (Aw): It was measured in an AquaLab water activity meter, METER, AquaLab 3 T series (U.S.A); approximately $1 \mathrm{~g}$ of flour sample was placed into a special white capsule, so that it covered the complete surface of the capsule. Then, the capsules were introduced in the equipment and the measurements were performed at $25^{\circ} \mathrm{C}$.

\section{Technological properties of flours}

The water absorption capacity (WAC) was performed according to Elmi et al. (2017) with some modifications; $5 \mathrm{~g}$ of flour samples were weighed in $50 \mathrm{~mL}$ Falcon tubes, mixed mechanically with $30 \mathrm{~mL}$ of distilled water in an automatic shaker (Multi Reax, Germany) at 1875 rpm for 30 min. After that, the tubes were centrifuged at $3328 \mathrm{rpm}$ for $25 \mathrm{~min}$ in a centrifuge (model Eppendorf 5430R, Germany). The supernatant was discarded carefully, and the tubes were placed in a Marconi MA385/3 drying oven (Piracicaba, Brazil) at $50{ }^{\circ} \mathrm{C}$ for $25 \mathrm{~min}$. WAC was calculated according to the following equation: 


$$
A C(\%)=\left[\frac{(\text { sediment sample weight }(g)-\text { initial sample weight }(g))}{\text { initial sample weight }(g)}\right] X 100
$$

The oil absorption capacity (OAC) was determined following the method used by Jan et al. (2016); $4 \mathrm{~g}$ flour samples were mixed with $24 \mathrm{~mL}$ of vegetable oil and shaken manually every $5 \mathrm{~min}$ for a period of $30 \mathrm{~min}$. Afterwards, samples were centrifuged at $3328 \mathrm{rpm}$ for 25 minutes and the supernatant was discarded carefully. The OAC value was calculated using the following equation:

$$
O A C(\%)=\left[\frac{(\text { final weight }- \text { initial weight })}{(\text { initial weight })}\right] \times 100
$$

The emulsifying capacity (EC) was determined through the method used by Chaparro et al. (2014); samples of $0.875 \mathrm{~g}$ were mixed with $12.5 \mathrm{~mL}$ of vegetable oil and 12.5 $\mathrm{mL}$ of distilled water, homogenized in an ultra turrax IKA T25 digital (Germany) at $10000 \mathrm{rpm}$ for $1 \mathrm{~min}$ and centrifuged at $10000 \mathrm{rpm}$ for $5 \mathrm{~min}$. The formed emulsion layer was measured with an Electronic Digital Vernier Caliper (Rosimo Stainless Hardened, Louisware 13, Japan) with a minimal resolution of $0.01 \mathrm{~mm}$. The $\mathrm{EC}$ value was calculated using the following equation:

$$
E C(\%)=\left[\frac{(\text { emulsion layer height })}{(\text { total height of dispersion })}\right] \times 100
$$

The emulsion stability (ES) was determined following the method used by Chaparro et al. (2014). Samples of 0.875 $\mathrm{g}$ were mixed with $12.5 \mathrm{~mL}$ of vegetable oil and $12.5 \mathrm{~mL}$ of distilled water, homogenized at $10000 \mathrm{rpm}$ for $1 \mathrm{~min}$, the sample tubes then placed in a Marconi MA 159 hot water bath (Piracicaba, Brazil) at $80^{\circ} \mathrm{C}$ for $30 \mathrm{~min}$, and then cooled to room temperature for $25 \mathrm{~min}$. The ES was calculated using the following equation:

$$
E S(\%)=\left[\frac{(\text { height of emulsion layer after heating })}{(\text { total height of dispersion })}\right] X 100
$$

\section{Cookie formulation}

Different cookie formulations were prepared (Table 1) according to Alves et al. (2018), with some modifications. Sugar and margarine were mixed for $1 \mathrm{~min}$ in a mixer bowl (3.5 L) using a Kitchen Aid KPM5 (Ohio, U.S.A) with a flat beater. Then, the other ingredients were added and mixed for $5 \mathrm{~min}$. Subsequently, the dough was rolled to a $5 \mathrm{~mm}$ thickness, followed by cutting into $5-\mathrm{cm}$ diameter circular portions. Cookies were baked at $130^{\circ} \mathrm{C}$ for $15 \mathrm{~min}$ and cooled for $45 \mathrm{~min}$. After cooling, cookies were packaged in laminated pouches.
Table 1. Cookies composition ( $\mathrm{g} / 100 \mathrm{~g}$ ) in formulations with rice and chayotextle flour

Tabla 1. Composición (g/ 100 g) de galletas en formulaciones con harinas de arroz y chayotextle

\begin{tabular}{lcccccccc}
\hline & \multicolumn{7}{c}{ Ingredients (g/ 100 g) } \\
\cline { 2 - 5 } & CF & RF & AF & $\begin{array}{c}\text { Brown } \\
\text { sugar }\end{array}$ & Butter & $\begin{array}{c}\text { Egg } \\
\text { white }\end{array}$ & $\begin{array}{c}\text { Baking } \\
\text { powder }\end{array}$ & Salt \\
\hline RF-100 & 0 & 100 & 0 & 14.5 & 23.2 & 12.0 & 0.2 & 0.1 \\
CF-100 & 100 & 0 & 0 & 14.5 & 23.2 & 12.0 & 0.2 & 0.1 \\
RF-CF-AF & 50 & 50 & 12 & 14.5 & 23.2 & 12.0 & 0.2 & 0.1 \\
RF-CF & 50 & 50 & 0 & 14.5 & 23.2 & 12.0 & 0.2 & 0.1 \\
CF-AF & 100 & 0 & 12 & 14.5 & 23.2 & 12.0 & 0.2 & 0.1 \\
\hline
\end{tabular}

RF: Rice flour; CF: Chayotextle flour; AF: Agave fructans

\section{Cookies characterization}

Diameter, thickness and spreading factor: Cookie samples diameter and thickness were determined using a micrometer in eight different points of the cookie. The spreading factor (S.F.) represents the ratio between diameter and thickness, and was calculated using the following equation:

$$
S . F=\frac{\text { diameter }(\mathrm{mm})}{\text { thickness }(\mathrm{mm})}
$$

Specific volume: The specific volume of cookies was determined using a VolScan Stable Micro system, Godalming (United Kingdom) equipment. The measurements were obtained directly from the equipment; the units were expressed in $\mathrm{g} / \mathrm{mL}$ (Smewing, 2016).

Hardness: Cookies hardness was determined according to Bárcenas and Rosell (2005), using a Texture Analyzer texturometer, TAXT2i (United Kingdom), with a 5 kg load cell, a $2.5 \mathrm{~cm}$ diameter $\mathrm{P} / 25$ cylinder device, and a pre- and posttest speed of $2.0 \mathrm{~mm} / \mathrm{s}$ and $10.0 \mathrm{~mm} / \mathrm{s}$, respectively.

Moisture, $\mathbf{p H}$ and color were determined following the same procedure as for flours. To measure the $\mathrm{pH}$ of cookies, they were ground into flour as described previously, from which $10 \mathrm{~g}$ of powdered samples were weighed, and $100 \mathrm{~mL}$ of distilled water was added to each sample.

\section{Prebiotic effect}

The microbiological test used to evaluate prebiotic effect in CF and the CF-AF cookie formulation was according to the methodology proposed by China et al. (2012), with some modifications. For this purpose, the microorganisms were activated in $10 \mathrm{~mL}$ of MRS broth and incubated at 37 ${ }^{\circ} \mathrm{C}$ for $20 \mathrm{~h}$. Afterwards, cells were collected by centrifugation at $7000 \mathrm{rpm}$, at $10{ }^{\circ} \mathrm{C}$ for $5 \mathrm{~min}$ and washed twice with $2 \%$ sodium citrate solution. Finally, cells were re-suspended in a $2 \%$ sodium citrate solution to approximately 9 log CFU/mL.

MRS broth was supplemented with $3 \%$ CF or $3 \%$ CFAF cookie formulation, while MRS broth without supplemen- 
tation was used as a control. Then, $10 \mu \mathrm{L}$ of each bacterial suspension were added to supplemented MRS broth and control. Tubes were incubated at $37{ }^{\circ} \mathrm{C}$ for 3 days. Finally, aliquots for each tube were removed during incubation ( $t=$ $0,24,48$ and $72 \mathrm{~h}$ ) to perform the bacterial count, using an electronic bacteria counter, taking into account the colonies that showed between 10-50 UFC.

\section{Statistical analysis}

Statistical analysis was performed using a completely randomized design with Design Expert 6.0 software and expressed as the average \pm the standard deviation of three replicates. Results were analyzed using an analysis of variance (one way-ANOVA) checking that the distribution of the data was normal. Then, a comparison of means by the Tukey test (IS Infostat Version 2017 software) with a significance level of $\mathrm{p}<0.05$ was applied.

\section{RESULTS AND DISCUSSION \\ Physicochemical properties of flours}

Table 2 shows the results obtained from the physical and physicochemical properties of CF and RF. CF had a higher moisture content compared to RF. This behavior could be explained due to the fact that CF was obtained from a tuberous root whose main component is water $(74.2 \%$, approximately), which was subjected to oven drying at low temperature $\left(50{ }^{\circ} \mathrm{C}\right)$, and therefore, it could have conserved part of the initial moisture. On the other hand, RF was obtained from a cereal that normally contains an initial moisture $<14 \%$, although that value may change depending on the variety or type of rice. The moisture content for Brazilian rice flour obtained in this study was $8.62 \%$, however, Hu et al. (2020a) reported a moisture of $12.26 \%$ in Japonica rice flour and Hamdani et al. (2020), found a moisture of approximately $9.2 \%$. Therefore, the moisture content value obtained in this study is among these reported values. Statistically a significant difference was found with a value of $\mathrm{P}<0.05$ in the moisture content between both flours. The $\mathrm{pH}$ values obtained from both flours were neutral, while in water activity, no significant difference was found. The moisture content of flours is of great importance in the production of cookies and bakery products, because if the water content is insufficient in the cookie dough, most of the starch granules do not gelatinize during the cookie baking process. This could lead to more consistency or hardness and consumer rejection. On the other hand, the flours must not contain more than $14 \%$ moisture because this promotes bacterial growth (Mancebo et al., 2016).

Table 2. Physical and physicochemical properties of chayotextle and rice flours Tabla 2. Propiedades físicas y fisicoquímicas de harinas de chayotextle y arroz

\begin{tabular}{lcc}
\hline Parameter & Chayotextle Flour & Rice Flour \\
\hline Moisture Content (\%) & $9.85 \pm 0.13^{\mathrm{a}}$ & $8.62 \pm 0.03^{\mathrm{b}}$ \\
$\mathrm{a}_{\mathrm{w}}$ & $0.43 \pm 0.01^{\mathrm{a}}$ & $0.41 \pm 0.01^{\mathrm{a}}$ \\
$\mathrm{pH}$ & $7.09 \pm 0.001^{\mathrm{a}}$ & $6.77 \pm 0.01^{\mathrm{b}}$ \\
$\mathrm{L}^{*}$ & $82.79 \pm 2.83^{\mathrm{b}}$ & $86.64 \pm 2.79^{\mathrm{a}}$ \\
$\mathrm{a}^{*}$ & $0.95 \pm 0.11^{\mathrm{a}}$ & $0.40 \pm 0.07^{\mathrm{b}}$ \\
$\mathrm{b}^{*}$ & $17.65 \pm 0.53^{\mathrm{a}}$ & $7.72 \pm 0.58^{\mathrm{b}}$ \\
\hline
\end{tabular}

Values expressed as mean \pm standard deviation. Different letters show significant difference by Tukey test $(p<0.05)$. Where $L^{*}, a^{*}$ and $b^{*}$ are coordinates of the CIE-Lab system.
The color results showed that RF presented a higher luminosity value. The values of $a^{*}$ and $b^{*}$ in both flours were positive, showing closer proximity to red and yellow, respectively. The highest $a^{*}$ and $b^{*}$ values were obtained with $C F$, resulting in a darker color than RF. This behavior could be the result of the enzymatic darkening that the Chayotextle suffered during the peeling and cutting process, since it contains a significant amount of the Polyphenoloxidase enzyme. Likewise, this could be due to the drying temperature $\left(50^{\circ} \mathrm{C}\right)$, which could cause some darkening reactions in the flour. $L^{*}$, $a^{*}$ and $b^{*}$ showed significant differences with a value of $\mathrm{P}<$ 0.05 . The difference in the color of the flours could represent an inconvenience of mixing them in the preparation of cookies, resulting in a dark color, which could be unpleasant for consumers.

\section{Flour technological properties}

Technological properties have great relevance in bakery products because they play an important role in cookie quality. These properties show an idea on how the effect in dough rheology, spread and water absorption during baking will be (Mancebo et al., 2016). Figure 1 presents the technological properties for CF and RF. CF showed a higher water absorption capacity than RF. This behavior could be explained by the large amount of starch that Chayotextle contains in its composition (65-72\%) (Shiga et al., 2015) and its chemical characteristics. Chayotextle starch contains a significant amount of phosphorous attached to its structure in the form of phosphate groups, which provides a strong hydrophilic character that allows it to absorb and retain large amounts of water, increasing the capacity of water bonds. These characteristics of Chayotextle starch are consistent with that reported by Jiménez et al. (2007). While rice flour, despite containing a significant amount of starch, it generally produces gels with a tendency for rapid retrogradation

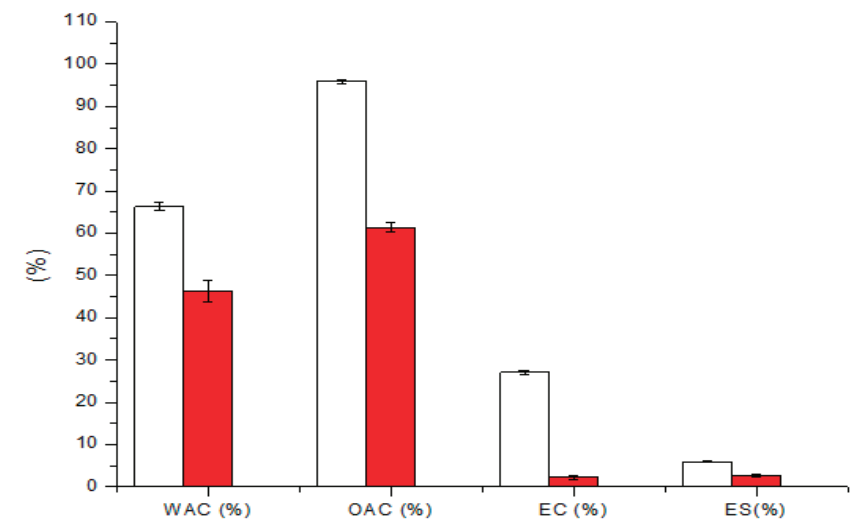

Figure 1. Technological properties of Chayotextle and rice flours. White-Chayotextle flour; Red-rice flour. WAC: Water Absorption Capacity, OAC: Oil Absorption Capacity, EC: Emulsifying Capacity; ES: Emulsion Stability. Different letters at the same parameter, show significant difference by Tukey test $(p<0.05)$.

Figura 1. Propiedades tecnológicas de harinas de chayotextle y arroz. Blanco-harina de chayotextle; Rojo-harina de arroz. WAC: Capacidad de absorción de agua, OAC: Capacidad de absorción de aceite, EC: Capacidad emulsificante; ES: Estabilidad de la emulsión. Letras diferentes en un mismo parámetro, muestran diferencia significativa por prueba de Tukey $(p<0.05)$. 
with low water retention. Hu et al. (2020b) reported that this type of behavior in the production of rice flour gels is mainly due to the structure of the starch, its size and its amylose-amylopectin proportion. Gels with lower amylose content are responsible for generating lower viscosity. There was a higher oil retention capacity in $\mathrm{CF}$ than in $\mathrm{RF}$, which could be due to the formation of starch-lipid complexes, carbohydrates-lipids, and fiber content (0.4\%) present (Vieira et al., 2019). The emulsifying capacity and emulsion stability values were higher for CF. This behavior is the result of large values of oil and water retention capacity, which is why the results show that $C F$ has a great ease to interact with both media. A significant difference was found for the case of all measured properties.

\section{Physical properties of cookies}

Table 3 shows the results of the physical properties analyzed for the different formulations of cookies. The values of diameter, thickness and specific volume were significantly influenced by the presence of $C F$, which caused a significant increase in the values of the formulations containing it $(63.42$ to $63.79 \mathrm{~mm}$ in diameter, $8.56 \mathrm{~mm}$ thick and 1.35 specific volume). However, the highest values correspond to the cookies containing both CF and FA (65.10 to $66.82 \mathrm{~mm}$ in diameter, 9.36 to $10.04 \mathrm{~mm}$ thick and 1.72 to $2.07 \mathrm{~mm}$ specific volume). This is possibly because fructans have the characteristic of being highly soluble, and thus promote the formation of gels that provide better baking characteristics in the cookies. Santiago et al. (2017) reported a similar behavior in wheat cookies with agave fructans.
The spreading factor is an important parameter in the evaluation of cookies since, according to Giuberti et al. (2017), cookies with higher spreading factor values are more desirable to consumers, because it represents the ratio between the diameter and the thickness of cookies. Likewise, it gives the impression of expansion during baking. The results showed that the combination of CF and RF potentiate this parameter, obtaining values from 6.4 to 9.04 . These values are higher than those found by Giuberti et al. (2017) in gluten-free rice cookies and gluten-free rice cookies with resistant starch, and by Kaur et al. (2017) in gluten-free flaxseed flour cookies, who reported values from 4.9 to 5.2 and 3.3 to 4.15 , respectively. However, the value decreased in the formulations with AF. No significant difference was found between the hardness values of formulations that only contained a single type of flour (79.35 N in RF and 87.73 $\mathrm{N}$ in CF) or a combination of CF and RF (122.55 N). Despite this, there was an influence on the hardness parameter by $A F$, since the RF-CF-AF formulation showed the highest value, $201.82 \mathrm{~N}$. This could be explained by the possible formation of complexes between the AF components and protein fractions of both flours (Santiago et al., 2017). The pH values did not show significant difference, constantly very close to neutral. According to the NMX-F-006-1983, these results are within the accepted quality $\mathrm{pH}$ parameters, of between 6.0 and 8.0 for cookies.

The color values obtained for $L^{*}$ and $a^{*}$ showed a significant difference for all formulations. Likewise, in general, all the formulations presented positive $a^{*}$ and $b^{*}$ values, with a trend towards reds and yellows. RF presented the highest

Table 3. Physical and texture properties of cookies

Tabla 3. Propiedades físicas y texturales de galletas

\begin{tabular}{|c|c|c|c|c|c|}
\hline \multirow{2}{*}{ Parameter } & \multicolumn{5}{|c|}{ Formulation } \\
\hline & RF-100 & CF-100 & RF-CF-AF & RF-CF & CF-AF \\
\hline Diameter (mm) & $61.06 \pm 1.08^{d}$ & $63.42 \pm 2.06^{c}$ & $65.10 \pm 1.11^{b}$ & $63.79 \pm 2.01^{c}$ & $66.82 \pm 0.44^{a}$ \\
\hline Thickness (mm) & $7.75 \pm 0.45^{d}$ & $8.56 \pm 0.76^{c}$ & $10.04 \pm 0.81^{a}$ & $7.14 \pm 0.86^{d}$ & $9.36 \pm 0.95^{b}$ \\
\hline Spreading factor & $7.90 \pm 0.42^{b}$ & $7.47 \pm 0.85^{b}$ & $6.53 \pm 0.57^{c}$ & $9.04 \pm 1.03^{a}$ & $7.21 \pm 0.78^{b}$ \\
\hline $\begin{array}{l}\text { Specific volume } \\
(\mathrm{mL} / \mathrm{g})\end{array}$ & $1.31 \pm 0.05^{c}$ & $1.35 \pm 0.68^{c}$ & $2.07 \pm 1.07^{\mathrm{a}}$ & $1.35 \pm 0.68^{c}$ & $1.72 \pm 0.87^{b}$ \\
\hline Hardness (N) & $79.35 \pm 7.07^{b}$ & $87.73 \pm 18.75^{b}$ & $201.82 \pm 58.36^{a}$ & $122.55 \pm 6.66^{b}$ & $72.67 \pm 4.83^{b}$ \\
\hline Moisture (\%) & $3.66 \pm 0.16^{d}$ & $7.98 \pm 0.20^{b}$ & $6.67 \pm 0.22^{c}$ & $10.43 \pm 0.66^{a}$ & $10.64 \pm 0.07^{a}$ \\
\hline $\mathrm{pH}$ & $6.60 \pm 0.02^{\mathrm{e}}$ & $6.97 \pm 0.01^{b}$ & $6.62 \pm 0.01^{d}$ & $7.04 \pm 0.01^{\mathrm{a}}$ & $6.85 \pm 0.01^{c}$ \\
\hline$L^{*}$ & $64.68 \pm 0.31^{a}$ & $57.63 \pm 0.83^{d}$ & $60.62 \pm 2.52^{c}$ & $63.03 \pm 1.71^{b}$ & $59.54 \pm 1.09^{c}$ \\
\hline$a^{*}$ & $9.76 \pm 0.46^{d}$ & $14.71 \pm 0.37^{a}$ & $13.90 \pm 1.06^{b}$ & $10.84 \pm 0.82^{c}$ & $13.88 \pm 0.46^{b}$ \\
\hline$b^{*}$ & $33.65 \pm 0.57^{d}$ & $38.62 \pm 0.45^{\mathrm{a}}$ & $36.81 \pm 0.28^{b}$ & $35.06 \pm 2.53^{c}$ & $35.96 \pm 0.34^{b c}$ \\
\hline
\end{tabular}

Values expressed as mean \pm standard deviation. Different letters show significant difference by Tukey test $(p<0.05)$. Where $L^{*}$, $a^{*} y b^{*}$ coordinates of the CIELab system; RF: Rice flour; CF: Chayotextle flour; AF: Agave fructans. 
$L$ * value (64.68), followed by the formulations containing AF (60.62 RF-CF-AF and 59.54 CF-AF). While the CF-100 formulation made with only $C F$ showed the lowest value (57.63). An inverse behavior was found for $\mathrm{a}^{*}$ where cookies prepared only with RF, showed the lowest value (9.76). Only cookies made with a single type of flour showed a significant difference for $b^{*}$ (33.65 in RF and 38.62 in CF). In general, the presence of CF produced a darker color in the cookies, perceived with the naked eye. This could be because CF has a high carbohydrate content, which in the presence of proteins promotes the Maillard reactions and the generation of brown compounds during baking. Kaur et al. (2019) reported a similar effect in cookies made from flaxseed flour. Normally, consumers prefer cookies with similar color than wheat flour cookies, for this reason, the darkening of the cookies made with Chayotextle flour can be a positive effect (Mancebo et al., 2016).

\section{Prebiotic capacity}

The prebiotic capacity was measured only on CF and CF-AF formulations because these displayed favorable cookie properties, such as greater values of diameter, thickness, specific volume. Lactobacillus and Bifidobacterium constitute a major part of the intestinal microflora in animals and humans, playing an important role as a barrier to prevent pathogenic bacterium entrance. Likewise, a selective simulation of the growth and activity of beneficial microorganisms can be possible by addition of prebiotics (China et al., 2012). Fig. 2 shows the results obtained for L. acidophilus LA-3 in the period from 0 to $24 \mathrm{~h}$, where the exponential phase was obtained and there was an increase in the amount of CFU for both samples (CF and CF-AF formulations). The probiotic strain consumed the glucose in the medium, increasing in two logarithmic cycles, reaching a population density of 9.8 $\log 10$ CFU / mL (glucose), $9.82 \log 10$ CFU / mL (CF) and 9.58 log10 CFU / mL (CF-AF). These results are similar to those obtained by Ayala et al. (2018), who reported values of 9.55 log10 CFU / mL (glucose), $9.34 \log 10$ CFU / mL (agave inulin) for Lactobacillus casei and $9.36 \log 10$ CFU / mL (agave inulin) for Lactobacillus salivarius. The study of inulin fermentation by lactic acid bacteria by García et al. (2007) mentioned that there is a favorable consumption and good fermentability of inulin and fructooligosaccharides by lactic acid bacteria, which include different species of Lactobacillus, Streptococcus and Bifidobacteium. This behavior has been studied by various researchers who have concluded that the these bacterial strains have a mechanism capable of hydrolyzing the $\beta(2,1)$ bonds present in inulin. At $24 \mathrm{~h}$, no significant difference was found between the samples, since there was no increase in the growth of microorganisms. In the 24-48 interval, a number of probiotic colonies remained in the stationary phase for CF-AF, while for CF there was a slight decline in the growth curve. At $72 \mathrm{~h}$ of incubation, CF presented a higher CFU / $\mathrm{mL}$ value than the media supplemented only with glucose and $\mathrm{AF}$, probably because this flour represented a richer nutrient medium and carbon source for $L$. acidophilus

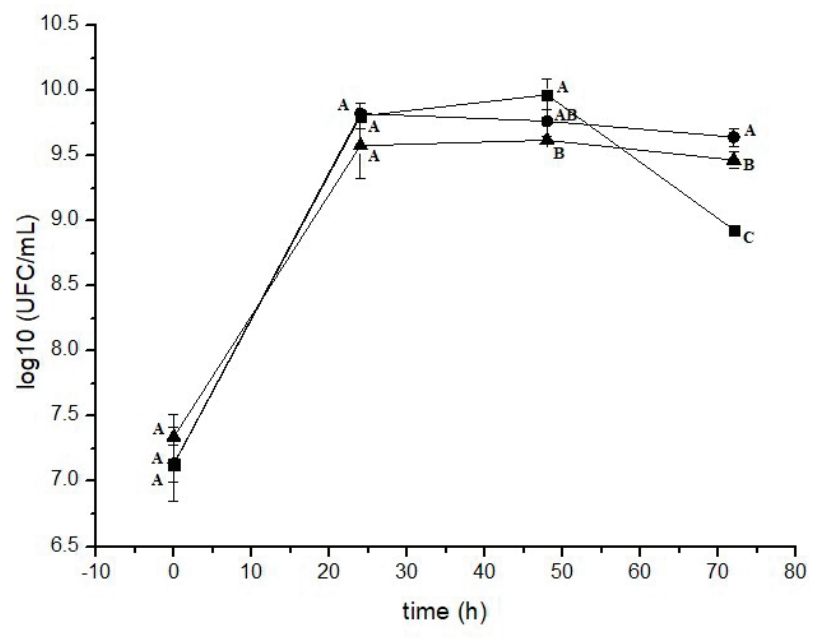

Figure 2. Prebiotic effect of Lactobacillus acidophilus in: MRS control supplemented with glucose ( $\mathbf{\square})$; MRS supplemented with $3 \%$ Chayotextle flour (•); MRS supplemented with $3 \%$ Chayotextle and fructans flour $(\boldsymbol{\Delta})$. Different letters at the same times, show significant difference by Tukey test $(p<0.05)$.

Figura 2. Efecto prebiótico de Lactobacillus acidophilus en: Control MRS suplementado con glucosa (घ); MRS suplementado con harina de chayotextle al $3 \%(\bullet)$; MRS suplementado con harina de chayotextle y fructanos al $3 \%$ $(\boldsymbol{\Delta})$. Letras diferentes a los mismos tiempos, muestran diferencia significativa por prueba de Tukey $(\mathrm{p}<0.05)$.

LA-3. Meanwhile, for the glucose-enriched sample (control), the population density decreased one logarithmic cycle in the 48-72 hours interval, reaching a value of $8.93 \log 10$ CFU $/ \mathrm{mL}$. Even so, it is likely that if the incubation time had been increased by more than $72 \mathrm{~h}$, the probiotic bacteria would still have remained longer in the CF sample.

A notable increase in the bacterial population of both samples was obtained for $B$. animalis subsp. Lactis during the 0-24 h interval (logarithmic phase), as shown in Fig. 3. Bacterial density was increased in a logarithmic cycle for media enriched with glucose and $\mathrm{CF}-\mathrm{AF}$, reaching values of $8.96 \log 10 \mathrm{CFU} / \mathrm{mL}$ and $9.68 \log 10 \mathrm{CFU} / \mathrm{mL}$, unlike that obtained with Lactobacillus acidophilus, where it increased in two cycles. On the other hand, for CF the increase was two logarithmic cycles, obtaining a value of $9.85 \log 10$ CFU $/ \mathrm{mL}$. Despite this, no significant difference was found in the number of CFUs at $24 \mathrm{~h}$ between samples. During the $24-48 \mathrm{~h}$ period, the stationary phase occurred in the CF sample. While for the CF-AF formulation there was a slight increase in the probiotic population at $48 \mathrm{~h}$. The number of CFU in B. animalis subsp. Lactis decreased slightly in the medium added with CF from 48-72 $\mathrm{h}$, which showed that at that time the bacteria had consumed most of the substrate and therefore began to enter the bacterial death phase. Meanwhile, the probiotic population in the medium supplemented with CFAF continued to increase. This could be explained by the fact that bifidobacteria prefers consuming the short and simple sugar chains first, and then continue with the consumption of other oligofructose chains. Van der Meulen et al. (2006) found this type of behavior when analyzing the mechanism 


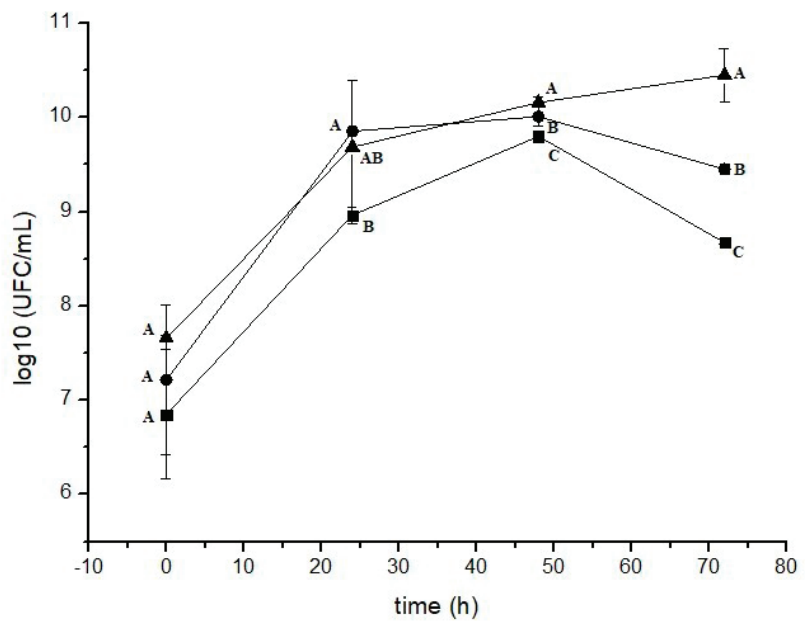

Figure 3. Prebiotic effect of Bifidobacterium animalis subsp. Lactis in: MRS control supplemented with glucose (घ); MRS supplemented with $3 \%$ Chayotextle flour $(\bullet)$; MRS supplemented with $3 \%$ Chayotextle and agave fructans flour $(\boldsymbol{\Lambda})$. Different letters at the same time, show significant difference by Tukey test $(p<0.05)$.

Figura 3. Efecto prebiótico de Bifidobacterium animalis subsp. Lactis en: Control MRS suplementado con glucosa ( $($ ); MRS suplementado con harina de chayotextle al $3 \%(\bullet)$; MRS suplementado con harina de chayotextle y fructanos al $3 \%$ ( $\mathbf{\Delta}$ ). Letras diferentes a los mismos tiempos, muestran diferencia significativa por prueba de Tukey $(p<0.05)$.

of oligofructose consumption by Bifidobacterium spp. In the same way, Ayala et al. (2018) reported that bacteria of the Bifidobacterium genus have a high affinity for low molecular weight fructans, unlike Lactobacillus that ferment high and low molecular weight fructans.

The control medium, supplemented with glucose, showed an evident decrease in the number of CFUs, decreasing in a logarithmic cycle from $48-72 \mathrm{~h}$, which indicated that the Bifidobacteria consumed all the glucose in the medium and consequently began to die. Van der Meulen et al. (2006) reported that glucose and fructose are not good substrates for the growth of the Bifidobacterium animalis DN 173010 strain.

In general, a higher growth was obtained for both strains in the media supplemented with CF and CF-AF at 72 $\mathrm{h}$, reaching population density values of $9.45 \log 10 \mathrm{CFU} / \mathrm{mL}$ and $10.45 \log 10 \mathrm{CFU} / \mathrm{mL}$ respectively, while for glucose it was $8.67 \log 10 \mathrm{CFU} / \mathrm{mL}$. However, the prebiotic capacity of the substrate depended on the type of bacterial strain. This coincides with Vieira et al. (2017), who suggested that the fermentability of the substrate depends on the type of substrate and strain species used, evaluating the growth of probiotic bacteria on different substrates of fruit by-products, soybeans and amaranth. They found that the Lactobacillus acidophilus LA-5 and Lactobacillus ramnosus LGG species had a reduction in their population density at 24 and 48 hours of incubation for plant substrates, while the strains of Bifidobacterium animalis BB-12 and Bifidobacterium longum presented an increase in the bacterial population for all substrates from fruits and vegetables.

\section{CONCLUSIONS}

The agave fructans showed a good performance in the preparation of cookies, since they improved the physical and textural characteristics of the product while increasing the diameter and thickness. The addition of AF represents a benefit for CF cookies, since they promote the growth of both microorganisms: Lactobacillus acidophilus and Bifidobacterium animalis subsp. lactis. Finally, we demonstrated that Chayotextle flour had a prebiotic effect for both strains; therefore, this type of flour may be a promising alternative for bakery products because it has prebiotic characteristics not found in other types of flour.

\section{ACKNOWLEDGEMENTS}

The first author wishes to thank CONACYT Mexico, for the scholarship support provided during the research study. To the coordination of academic cooperation of the Instituto Politécnico Nacional, Centro de Desarrollo de Productos Bióticos (CEPROBI) for donating the agave fructans used in this project and the FZEA University of Sao Paulo, Brazil for the support in its facilities.

\section{CONFLICT OF INTEREST}

The authors declare that there is no conflict of interest.

\section{REFERENCES}

AOAC. 2006. Official Methods of analysis. 18th ed. Association of Official Analytical Chemists. Washington, D.C.

Ayala Monter, M. A., Hernández Sánchez, D., Pinto Ruiz, N., González Muñoz, Sergio S., Bárcena Gama, J. R., Hernández Mendo, O., \& Torres Salado, N. (2018). Efecto prebiótico de dos fuentes de inulina en el crecimiento in vitro de Lactobacillus salivarius y Enterococcus faecium. Revista Mexicana de Ciencias Pecuarias, 9(2), 346-361. http://dx.doi. org/10.22319/rmcp.v9i2.4488.

Bárcenas, M. E. \& Rosell, C. M. (2005). Effect of HPMC addition on the microstructure, quality and aging of wheat bread. Food Hydrocolloids, 19(6), 1037-1043. https://doi.org/10.1016/j. foodhyd.2005.01.005

Chandrasekara, A. \& Kumar, T. J. (2016). Roots and Tuber Crops as Functional Foods: A Review on Phytochemical Constituents and Their Potential Health Benefits. International Journal of food Science. 1-15. https://doi.org/10.1155/2016/3631647

Chaparro, S.P., Tavera, M.L., Martínez, J.J \& Gil, J.H. (2014). Propiedades funcionales de la harina y de los aislados proteicos de la semilla de guanábana (Annona muricata). Revista U.D.C.A. Actualidad \& Divulgación Científica, 17(1), 151-159. https://doi.org/10.31910/rudca.v17.n1.2014.950

China, R., Mukherjee, S., Sen, S, Bose, S., Datta, S., Koley, H., Ghosh, S., \& Dhar, P. (2012). Antimicrobial activity of Sesbania grandiflora flower polyphenol extracts on some pathogenic bacteria and growth stimulatory effect on the probiotic organism Lactobacillus acidophilus. Microbiological Research, 167(8), 500-506. https://doi.org/10.1016/j. micres.2012.04.003

Cruz Villegas, R. (2017). Estudios científicos relacionados a la raíz tuberizada de chayote (Sechium edule), revisión. Boletín de ciencias agropecuarias Del ICAP, 3(5). https://doi. org/10.29057/icap.v3i5.2061 
Cuevas-Juárez, E., Ávila-Fernández, A., \& López-Munguía, A. (2017). Identification of enzymatic activities involved in agave fructan consumption by Bifidobacterium longum subsp. infantis ATCC 15697. Journal of functional foods, 35, 267-278. https://doi.org/10.1016/j.jff.2017.05.048

Da Silva, T. F. \& Conti-Silva, A. C. (2018). Potentiality of glutenfree chocolate cookies with added inulin/oligofructose: Chemical, physical and sensory characterization. LWTfood Science and Technology, 90, 172-179. https://doi. org/10.1016/j.Iwt.2017.12.031

De Paulo Farias, D., Fernandes de Araújo, F., Neri-Numa, I.A \& Pastore, G.M. (2019). Prebiotics: Trends in food, health and technological applications. Trends in food Science \& Technology, 93, 23-35. https://doi.org/10.1016/j. tifs.2019.09.004

Drabińska, N., Zieliński, H. \& Krupa-Kozak, U. (2016). Technological benefits of inulin-type fructans application in gluten-free products. Trends in Food Science \& Technology, 56, 149-157. https://doi.org/10.1016/j.tifs.2016.08.015

Elmi Sharlina, M.S., Yaacob, W.A., Lazim, A.M., Fazry, S., Lim, S. J., Abdullah, S., Noordin, A., Kumaran, M. (2017). Physicochemical properties of starch from Discorea pyrifolia tubers. Food Chemistry, 220, 225-232. https://doi. org/10.1016/j.foodchem.2016.09.196

Fuentes-Berrio, L., Acevedo-Correa, D. \& Gelvez-Ordoñez, V.M. (2015). Alimentos funcionales: Impacto y retos para el desarrollo y bienestar de la sociedad colombiana. Biotecnología en el sector agropecuario y agroindustrial, 13(2), 140-149. http://dx.doi.org/10.18684/BSAA(13)140149.

García, Y., Boucourt, R., Albelo, N. \& Nuñez, O. (2007). Fermentación de inulina por bacterias ácido-lácticas con características probióticas. Revista Cubana de Ciencia Agrícola, 41(3), 263-266. https://www.redalyc.org/artículo. oa?id=193017693011

Giuberti, G., Marti, A., Fortunati, P \& Gallo, A. (2017). Gluten free rice cookies with resistant starch ingredients from modified waxy rice starches: Nutritional aspects and textural characteristics. Journal of Cereal Science, 76, 157-164. https://doi.org/10.1016/i.jcs.2017.06.008

González Victoriano, L., Hernández Uribe, J., \& Güemes Vera, N. (2017). Chayotextle (Sechium edule), posible ingrediente en la elaboración de los productos libres de gluten. Boletín De Ciencias Agropecuarias Del ICAP, 3(5). https://doi. org/10.29057/icap.v3i5.2065.

Hamdani, A.M., Wani, I.A \& Bhat, N.A. (2020). Gluten free cookies from rice-chickpea composite flour using exudate gums from acacia, apricot and karaya. Food Bioscience, 35. https:// doi.org/10.1016/j.fbio.2020.100541

Hu, W. X., Chen, J., Xu, F., Chen, L., \& ZhaoJ-W. (2020a). Study of crystalline, gelatinization and rheological properties of Japonica rice flour as affected by starch fine structure. International Journal of Biological Macromolecules, 148, 1232-1241. https://doi.org/10.1016/j.ijbiomac.2019.11.020

Hu, W. X., Chen, J., Zhao, J. W., Chen, L. \& Wang, Y. H. (2020b). Effect of the addition of modified starch on gelatinization and gelation properties of rice flour. International Journal of Biological Macromolecules. 153, 26-35. https://doi. org/10.1016/j.ijbiomac.2019.11.020

Jan, R., Saxena, D.C. \& Singh, S. (2016). Physicochemical, textural, sensory and antioxidant characteristics of gluten free cookies made from raw and germinated Chenopodium (Chenopodium album) flour. LWT- Food Science and Technology, 71, 281-287. https://doi.org/10.1016/j. Iwt.2016.04.001

Jiménez-Hernández, J., Salazar-Montoya, J.A. \& RamosRamírez, E.G. (2007). Physical, chemical and microscopic characterization of a new starch from chayote (Sechium edule) tuber and its comparison with potato and maize starches. Carbohydrate polymers, 68, 679-686. https://doi. org/10.1016/j.carbpol.2006.07.035

Kaur, P., Sharma, P., Kumar, V., Panghal, A., Kaur, J., \& Gat, Y. (2017). Effect of addition of flaxseed flour on phytochemical, physicochemical, nutritional, and textural properties of cookies. Journal of the Saudi Society of Agricultural Sciences, 30, 1-6. https://doi.org/10.1016/j.jssas.2017.12.004

Koenen, M. E., Cruz Rubio, J. M., Mueller, M., \& Venema, K. (2016). The effect of agave fructan products on the activity and composition of the microbiota determined in a dynamic in vitro model of the human proximal large intestine. Journal of Functional Foods, 201-210. https://doi.org/10.1016/j. jff.2016.01.018

Leidi, E.O., Altamirano A. M., Mercado, G., Rodríguez, J. P., Ramos, A., Alandia, G., Sørensen, M., \& Jacobsen, S.-E. (2018). Andean roots and tubers crops as sources of functional foods. Journal of Functional Foods, 51, 86-93. https://doi. org/10.1016/j.jff.2018.10.007

Luo, D., Li, Y., Xu, B., et al. (2017). Effects of inulin with different degree of polymerization on gelatinization and retrogradation of wheat starch. Food Chemistry, 229, 35-43. https://doi.org/10.1016/j.foodchem.2017.02.058

Mancebo, C.M., Rodríguez, P. \& Gómez, M. (2016). Assessing rice flour-starch-protein mixtures to produce gluten free sugar-snap cookies. LWT- food Science and Technology, 67, 127-132. http://dx.doi.org/10.1016/j.lwt.2015.11.045.

Mancilla-Margalli, N. A. \& López, M. G. (2006). Water-soluble carbohydrates and fructan structure patterns from Agave and Dasylirion species. Journal of Agricultural and Food Chemistry, 54, 7832-7839. https://doi.org/10.1021/ jf060354v

Moro, T. M. A., Celegatti, C. M., Pereira, A. P. A., Lopes, A. S., Barbin, D. F., Pastore, G. M. \& Cleici, M. T. P. S. (2018). Use of burdock root flour as a prebiotic ingredient in cookies. LWT- Food and Science Technology, 90, 540-546. https://doi.org/10.1016/j. Iwt.2017.12.059

NMX-F-006-1983. Alimentos. galletas. Food. cookie. Normas mexicanas. Dirección General de Normas.

Pérez Flores, J. G., Jaimez Ordaz, J., \& Contreras López, E. (2017). ¿Qué es un alimento funcional? Pädi Boletín Científico De Ciencias Básicas E Ingenierías Del ICBI, 4(8). https://doi. org/10.29057/icbi.v5i8.2047

Ritsema, T. \& Smeekens, S. (2003). Fructans: beneficial for plants and humans. Current Opinion in Plant Biology, 6, 223-230. https://doi.org/10.1016/S1369-5266(03)00034-7

Romano, N., Sciammaro, L., Mobili, P., Puppo, M. C., \& GomezZavaglia, A. (2019). Flour from mature Prosopis nigra pods as suitable substrate for the synthesis of prebiotic fructo-oligosaccharides and stabilization of dehydrated Lactobacillus delbrueckii subsp. bulgaricus. Food Research International, 121, 561-567. https://doi.org/10.1016/j. foodres.2018.12.016

Rubel, I. A., Pérez, E. E., Genovese, D. B., \& Manrique, G. D. (2014). In vitro prebiotic activity of inulin-rich carbohydrates extracted

Volumen XXIII, Número 2 
from Jerusalem artichoke (Helianthus tuberosus L.) tubers at different storage times by Lactobacillus paracasei. Food Research International, 62, 59-65. https://doi.org/10.1016/j. foodres.2014.02.024

Santiago-García, P. A., Mellado-Mojica, E., León-Martínez, F. M. \& López, M.G. (2017). Evaluation of Agave angustifolia fructans as fat replacer in the cookies manufacture. LWTFood Science and Technology, 77, 100-109. https://doi. org/10.1016/j.Iwt.2016.11.028

Sarmiento Rubiano, L. A. (2006). Alimentos funcionales, una nueva alternativa de alimentación. Orinoquia, 10 (1), 16-23. Consulted December 21, 2020. ISSN: 0121-3709. Disponible en: https://www.redalyc.org/articulo.oa?id=896/89610103

Shiga, T.M., Peroni-Okita, F. H. G., Carpita, N.C., Lajolo, F. M., \& Cordenunsi, B. R. (2015). Polysaccharide composition of raw and cooked Chayote (Sechium edule Sw.) fruits and tuberous roots. Carbohydrate polymers, 130, 155-165. https://doi. org/10.1016/j.carbpol.2015.04.055
Smewing, J. (2016). AACCI approved methods technical committee report on the collaborative study for a new $\mathrm{AACCI}$ method (10-16.01): Volumetric and dimensional profile determination of baked products using laser topographyvolscan profile. Cereal Foods World, 61(1), 18-23. https://doi. org/10.1094 / CFW-61-1-0018

Van der Meulen, R., Makras, L., Verbrugghe, K., Adriany, T., \& De Vuyst, L. (2006). In vitro kinetic analysis of oligofructose consumption by Bacteroides and Bifidobacterium spp. Indicates different degradation mechanisms. Applied and Environmental Microbiology, 72(2), 1006-1012. https://doi. org/10.1128/AEM.72.2.1006-1012.2006

Vieira, A.D.S., Bedani, R., Albuquerque, M.A.C., Biscola, V., \& Saad, S.M.I. (2017). The impact of fruit and soybean by-products and amaranth on the growth of probiotic and starter microorganisms. Food Research International, 97, 356-363. https://doi.org/10.1016/j.foodres.2017.04.026 